\title{
Population genetic structure of Brazilian shrimp species (Farfantepenaeus sp., F. brasiliensis, F. paulensis and Litopenaeus schmitti: Decapoda: Penaeidae)
}

\author{
Jaqueline Gusmão ${ }^{1,2}$, Cristiano Lazoski ${ }^{2}$ and Antonio M. Solé-Cava ${ }^{2,3}$ \\ ${ }^{1}$ Universidade Estadual do Rio de Janeiro, Instituto de Biologia Roberto Alcântara Gomes, \\ Departamento de Biologia Celular e Genética, Rio de Janeiro, RJ, Brazil. \\ ${ }^{2}$ Universidade Federal do Rio de Janeiro, Instituto de Biologia, Departamento de Genética, \\ Laboratório de Biodiversidade Molecular, Rio de Janeiro, RJ, Brazil. \\ ${ }^{3}$ University of Liverpool, Department of Environmental and Evolutionary Biology, \\ Port Erin Marine Laboratory, Isle of Man, United Kingdom.
}

\begin{abstract}
Penaeid shrimps are important resources for worldwide fisheries and aquaculture. In the Southwest Atlantic, Farfantepenaeus brasiliensis, F. paulensis, F. subtilis, Farfantepenaeus sp. and Litopenaeus schmittiare among the most important commercially exploited species. Despite their high commercial value, there is little information available on the different aspects of their biology or genetics and almost no data on their stock structure. We used allozymes to estimate variability levels and population genetic structure of $F$. brasiliensis, F. paulensis, $L$. schmitti and the recently detected species Farfantepenaeus sp. along as much as $4,000 \mathrm{~km}$ of Brazilian coastline. No population heterogeneity was detected in $F$. brasiliensis or $L$. schmitti along the studied area. In contrast, $F_{S T}$ values found for Farfantepenaeus sp. and F. paulensis indicate that the populations of those two species are genetically structured, comprising different fishery stocks. The largest genetic differences in F. paulensis were found between Lagoa dos Patos (South) and the two populations from Southeast Brazil. In Farfantepenaeus sp., significant differences were detected between the population from Recife and those from Fortaleza and llhéus.
\end{abstract}

Key words: Farfantepenaeus, Litopenaeus, allozymes.

Received: September 25, 2003; Accepted: July 19, 2004.

\section{Introduction}

Penaeid shrimps are important resources for worldwide fisheries and aquaculture (Sunden and Davis, 1991). Population genetics have proven valuable for estimating stock boundaries and genetic variability of wild shrimp populations for fisheries (Benzie, 2000).

Along the Brazilian coast, juvenile shrimps are caught in natural nursery areas by small vessels, while the commercial fleet harvest adult populations in the open sea (Valentini et al., 1991). As a result of the unrestricted past growth of the industrial fleet, of the increased number of small boats fishing in natural nurseries and estuaries and of environmental degradation, there is evidence of declining

Send correspondence to Jaqueline Gusmão. Universidade Estadual do Rio de Janeiro, Instituto de Biologia Roberto Alcântara Gomes, Departamento de Biologia Celular e Genética, Rua São Francisco Xavier 524, Maracanã, 20550-900 Rio de Janeiro, RJ, Brazil. E-mail: gusmao@ centroin.com.br. stocks of shrimps along the Brazilian coast. Farfantepenaeus brasiliensis, F. paulensis, F. subtilis and Litopenaeus schmitti are among the main commercially important Brazilian species (Neto, 1991; Valentini et al., 1991). Populations of $F$. brasiliensis and $F$. paulensis of the South/Southeast regions showed a decrease of $87.1 \%$ in relative stock abundance between 1965-1994 (Neto and Dornelles, 1996). A decline was also observed in populations of F. subtilis (Neto, 1991) and L. schmitti (Neto and Dornelles, 1996). Despite their high commercial value and the need to understand their stock structure, so that effective management measures can be applied, there is still little information available on their population genetics (the sole exception is the analysis of $F$. paulensis in the South of Brazil; Delevedove, 1996), and even the taxonomic status of some species has just recently been clarified. Genetic analyses revealed a new (cryptic) Brazilian species of Farfantepenaeus (Farfantepenaeus sp.; formerly Penaeus 
subtilis $^{1}$ ) ranging from Rio de Janeiro to Northeast Brazil, showing that Penaeus subtilis (sensu Pérez Farfante, 1969) was in fact a mixture of two different species (Gusmão et al., 2000; Maggioni et al., 2001).

In this paper we used allozymes to estimate the variability levels and the population genetic structure of four Brazilian species, F. brasiliensis, F. paulensis, L. schmitti and the new species, Farfantepenaeus sp., over a distance of approximately $4,000 \mathrm{~km}$ of coastline.

Different stocks were observed within populations of F. paulensis and of Farfantepenaeus sp., while no detectable heterogeneity could be observed for populations of $F$. brasiliensis and L. schmitti along the studied area.

\section{Material and Methods}

We collected 556 individuals of $F$. brasiliensis, $F$. paulensis, L. schmitti and Farfantepenaeus sp. from eight different sites along 4,000 km of Brazilian coastline, between October 1997 and September 1999. Sampling localities are indicated in Figure 1. Samples were stored on dry ice and transported to the laboratory where they were identified morphologically according to Pérez Farfante (1969). Muscle tissue was preserved in liquid nitrogen until required for allozyme analysis.

Horizontal $12.5 \%$ starch gel electrophoresis was carried out as previously described (Murphy et al., 1990; Gusmão et al., 2000). The 11 enzyme systems investigated are shown in Table 1. Allozyme patterns were visualised

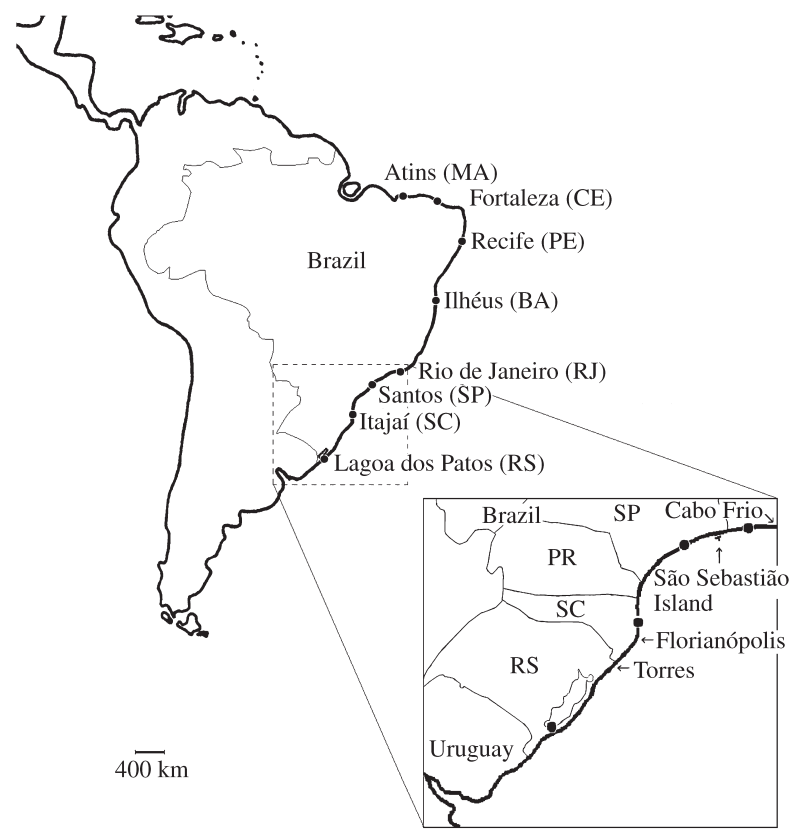

Figure 1 - (•) Sampling sites for the populations analysed. $(\rightarrow)$ Geographical limits of the main Farfantepenaeus paulensis offshore fishing area and adult congregation zones (see Discussion).
Table 1 - Enzymes studied (and abbreviations), Enzyme Commission numbers (E.C.), and buffer systems analysed.

\begin{tabular}{lccc}
\hline Enzyme & Abbrev. & E.C. & Buffer* \\
\hline Adenylate kinase & AK & 2.7 .4 .3 & TC8 \\
Isocitrate dehydrogenase & IDH & 1.1 .1 .42 & TC7 \\
Lactate dehydrogenase & LDH & 1.1 .1 .27 & TEM \\
Malic dehydrogenase & MDH & 1.1 .1 .37 & TC8 \\
Malic enzyme & ME & 1.1 .1 .40 & TEM \\
Mannose phosphate isomerase & MPI & 5.3 .1 .8 & TEM \\
Phosphoglucomutase & PGM & 5.4 .2 .2 & TC7 \\
Phosphogluconic dehydrogenase & PGD & 1.1 .1 .44 & TEM \\
Phosphoglucose isomerase & PGI & 5.3 .1 .9 & TC7 \\
Pro-Phe dipeptidase & PEP-A & 3.4 .13 .18 & TC8 \\
Tripeptidase (Leu-Gly-Gly) & PEP-B & 3.4 .11 .4 & TC8 \\
\hline
\end{tabular}

$*$ TEM $=0.10 \mathrm{M}$ Tris, 0.01 M EDTA, 0.10 M maleate, pH 7.4 (Brewer, 1970).

TC $8=0.25 \mathrm{M}$ Tris, $0.06 \mathrm{M}$ citrate, $\mathrm{pH} 8.0$ (Ward and Beardmore, 1977). $\mathrm{TC} 7=0.135 \mathrm{M}$ Tris, $0.043 \mathrm{M}$ citrate, $\mathrm{pH} 7.0$ (Shaw and Prasad, 1970).

using standard enzyme stains (Manchenko, 1994). Genotype frequencies were used to estimate gene frequencies, heterozygosities, tests for Hardy-Weinberg equilibrium, and inbreeding indices, using the BIOSYS- 1 programme version 1.7 (Swofford and Selander, 1981). The significance of $\mathrm{F}_{\mathrm{IS}}\left(\mathrm{H}_{\mathrm{O}}: \mathrm{F}_{\mathrm{IS}}=0\right)$ and $\mathrm{F}_{\mathrm{ST}}\left(\mathrm{H}_{\mathrm{o}}: \mathrm{F}_{\mathrm{ST}}=0\right)$ were tested according to Waples (1987).

The mean number of migrants $\left(\mathrm{N}_{\mathrm{e}} \mathrm{m}\right.$; Wright, 1978) between populations was estimated as $\left.\mathrm{N}_{\mathrm{e}} \mathrm{m} \approx\left(1 / \mathrm{F}_{\mathrm{ST}}\right)-1\right) / 4$. There have been concerns about the direct use of $\mathrm{F}_{\mathrm{ST}}$ to estimate gene flow (Whitlock and McCauley, 1999). However, $\mathrm{F}_{\mathrm{ST}}$ remains a robust estimate of multi-population differentiation when the number of loci analysed is not small (Neigel, 2002), so we chose to use it to facilitate comparison with data from the literature. We used a Mantel test (Sokal and Rohlf, 1995), between pairs of Farfantepenaeus and Litopenaeus populations, with 1000 replicates, to verify if geographic distances could be correlated to genetic distances.

\section{Results and Discussion}

The four species studied had distinct population structure patterns. Populations of Farfantepenaeus brasiliensis and Litopenaeus schmitti did not show any significant structuring $\left(\mathrm{F}_{\mathrm{ST}}=0.011\right.$ and 0.024 , respectively; $\chi^{2}$ test (Waples, 1987) null hypothesis: $\mathrm{F}_{\mathrm{ST}}=0 ; \mathrm{p}>0.05$ ) along the studied area. In contrast, the null hypothesis of panmixia was rejected $(\mathrm{p}<0.005)$ for populations of Farfantepenaeus sp. $\left(\mathrm{F}_{\mathrm{ST}}=0.032 ; \mathrm{N}_{\mathrm{e}} \mathrm{m}=5.31\right)$ and $F$. paulensis $\left(\mathrm{F}_{\mathrm{ST}}=0.045 ; \mathrm{N}_{\mathrm{e}} \mathrm{m}=7.56\right.$; Table 2$)$.

1 In a recent review, the subgenera Farfantepenaeus and Litopenaeus, formerly grouped under the Penaeus genus, were raised to generic level (Pérez Farfante and Kensley, 1997). 
Table 2 - Pair-wise $\chi^{2}$ values found between populations of Farfantepenaeus paulensis and of Farfantepenaeus sp.

\begin{tabular}{llcl}
\hline Species & \multicolumn{1}{c}{ Populations } & $\chi^{2} \mathrm{~F}_{\mathrm{ST}}$ & $\chi^{2}$ contingency \\
\hline F. paulensis & Santos/Lagoa dos Patos & $10.14^{* *}$ & $49.69^{* * *}$ \\
& Rio/Lagoa dos Patos & $9.26^{*}$ & $42.31^{* * *}$ \\
& Rio/Santos & $2.52^{\mathrm{NS}}$ & $25.71^{*}$ \\
Farfantepenaeus & Fortaleza/Recife & $5.13^{\mathrm{NS}}$ & $27.49^{*}$ \\
sp. & Fortaleza/Ilhéus & $2.59^{\mathrm{NS}}$ & $20.69^{\mathrm{NS}}$ \\
& Recife/Ilhéus & $4.96^{*}$ & $30.57^{* *}$ \\
\hline
\end{tabular}

NS - Not significant; $\mathrm{p}>0.05$.

$* \mathrm{p}<0.05 . *{ }^{*} \mathrm{p}<0.01 . * * * \mathrm{p}<0.001$

The mean value of $\mathrm{F}_{\mathrm{ST}}$ observed for the Brazilian populations of $L$. schmitti $\left(\mathrm{F}_{\mathrm{ST}}=0.024\right)$ is within the range reported for Cuban populations of the same species, using allozymes $\left(\mathrm{F}_{\mathrm{ST}}=0.021-0.038\right)$ and microsatellites $\left(\mathrm{F}_{\mathrm{ST}}=\right.$ 0.005-0.060; Espinosa et al., 2002). High genetic homogeneity has been reported for many other penaeid species (reviewed in Benzie, 2000).

The high $\mathrm{F}_{\mathrm{ST}}$ values found for Farfantepenaeus sp. and $F$. paulensis, even over shorter distribution ranges and using the same allozyme systems employed for $F$. brasiliensis and L. schmitti, indicate that the populations of those two species are genetically structured $(\mathrm{p}<0.005)$. Pair-wise comparisons of the populations (contingency $\chi^{2}$, Table 2) show that the largest population differences in $F$. paulensis were found between Lagoa dos Patos (South) and the two populations from Southeast Brazil $\left(\mathrm{p}<10^{-4}\right)$. In Farfantepenaeus sp., significant differences were detected between the population from Recife and those from Fortaleza $\left(\chi^{2}=27.49 ; \mathrm{p}<0.05\right)$ and Ilhéus $\left(\chi^{2}=30.57\right.$; $\mathrm{p}<0.01)$. Similar levels of population genetic structuring have also been observed for several species, e.g., Australian populations of Penaeus monodon (Benzie et al., 1992) and of Melicertus latisulcatus (Mulley and Latter, 1981); populations of $M$. kerathurus from the Mediterranean (Mattoccia et al., 1987); Cuban populations of $F$. notialis (Espinosa et al., 1996; García-Machado et al., 2001); and Californian populations of L. stylirostris (Aubert and Lightner, 1999; De La Rosa-Velez et al., 2000; RamosParedes and Grijalva-Chon, 2003) and of $F$. californiensis (De La Rosa-Velez et al., 2000).

Mean heterozygosity values observed for Brazilian species $(H=0.02-0.10)$ were similar to those reported in other surveys $(\mathrm{H}=0.006-0.175)$ (Benzie, 2000; GarcíaMachado et al., 2001; Espinosa et al., 2002; RamosParedes and Grijalva-Chon, 2003). The Mpi locus showed a relatively high variability among Farfantepenaeus species. This could be related to its tertiary structure (Solé-Cava and Thorpe, 1989) or to some hitherto unknown balanced selection regime acting on that locus. Gene frequencies at the 14 loci analysed, and mean heterozygosity values for each population are shown in Table 3.

Significant deviations from Hardy-Weinberg expectations (heterozygote deficiencies, $\mathrm{p}<0.05$; Fisher's exact test, corrected with Bonferroni series; Lessios, 1992) were found for the Pgm-1 locus in two populations of $F$. paulensis. Heterozygote deficiencies are common in marine invertebrates (Hare et al., 1996), and could indicate

Table 3 - Gene frequencies and sample sizes $(\mathrm{N})$ at 14 loci and 15 populations of Brazilian shrimp species. $\mathrm{H}_{0}, \mathrm{H}_{\mathrm{e}}$ : observed and expected heterozygosities, respectively.

\begin{tabular}{|c|c|c|c|c|c|c|c|c|c|c|c|c|c|c|c|}
\hline \multirow[t]{2}{*}{ Locus } & \multicolumn{5}{|c|}{ L. schmitti } & \multicolumn{3}{|c|}{ Farfantepenaeus sp. } & \multicolumn{4}{|c|}{ F. brasiliensis } & \multicolumn{3}{|c|}{ F.paulensis } \\
\hline & Atins & Fortaleza & Recife & Rio & Itajaí & Fortaleza & Recife & Ilhéus & Fortaleza & Ilhéus & Rio & Itajaí & Rio & Santos & L. Patos \\
\hline \multicolumn{16}{|l|}{$A k$} \\
\hline$(\mathrm{N})$ & (11) & (22) & (33) & (20) & (33) & (17) & (29) & (33) & (63) & (33) & $(48)$ & $(30)$ & (22) & (27) & (38) \\
\hline A & 0 & 0 & 0 & 0 & 0.02 & 0 & 0 & 0 & 0 & 0 & 0 & 0 & 0 & 0 & 0 \\
\hline B & 1 & 1 & 1 & 1 & 0.98 & 0 & 0 & 0 & 0 & 0 & 0 & 0 & 0 & 0 & 0 \\
\hline $\mathrm{C}$ & 0 & 0 & 0 & 0 & 0 & 0.03 & 0 & 0 & 0.02 & 0 & 0 & 0 & 0 & 0 & 0 \\
\hline $\mathrm{D}$ & 0 & 0 & 0 & 0 & 0 & 0 & 0 & 0 & 0 & 0 & 0 & 0 & 0 & 0 & 0 \\
\hline \multicolumn{16}{|l|}{$I d h$} \\
\hline$(\mathrm{N})$ & (38) & (24) & (35) & (34) & (35) & (15) & (30) & (49) & (77) & (33) & (48) & (30) & (22) & (27) & (40) \\
\hline A & 0 & 0.02 & 0 & 0 & 0 & 0 & 0 & 0 & 0 & 0 & 0 & 0 & 0 & 0 & 0 \\
\hline B & 1 & 0.98 & 1 & 1 & 1 & 1 & 1 & 1 & 1 & 1 & 1 & 1 & 1 & 1 & 1 \\
\hline \multicolumn{16}{|l|}{$L d h$} \\
\hline (N) & (38) & (24) & (35) & (34) & (35) & (17) & (30) & (49) & (80) & (33) & (48) & (30) & (22) & (27) & (40) \\
\hline A & 0 & 0.02 & 0 & 0 & 0 & 0 & 0 & 0 & 0 & 0 & 0 & 0 & 0 & 0 & 0 \\
\hline$M d h-1$ & & & & & & & & & & & & & & & \\
\hline$(\mathrm{N})$ & (38) & (25) & (35) & (34) & (35) & (17) & (30) & (49) & (80) & (33) & (48) & (30) & (22) & (27) & (40) \\
\hline A & 0 & 0 & 0 & 0 & 0 & 0 & 0 & 0 & 0 & 0.02 & 0 & 0 & 0 & 0 & 0.01 \\
\hline B & 0 & 0 & 0 & 0 & 0 & 0 & 0 & 0 & 0 & 0 & 0 & 0 & 0 & 0 & 0 \\
\hline $\mathrm{C}$ & 1 & 1 & 1 & 1 & 1 & 0.97 & 1 & 1 & 0.98 & 0.98 & 1 & 1 & 1 & 1 & 0.99 \\
\hline D & 0 & 0 & 0 & 0 & 0 & 0.03 & 0 & 0 & 0.01 & 0 & 0 & 0 & 0 & 0 & 0 \\
\hline $\mathrm{E}$ & 0 & 0 & 0 & 0 & 0 & 0 & 0 & 0 & 0.01 & 0 & 0 & 0 & 0 & 0 & 0 \\
\hline
\end{tabular}


Table 3 (Cont.)

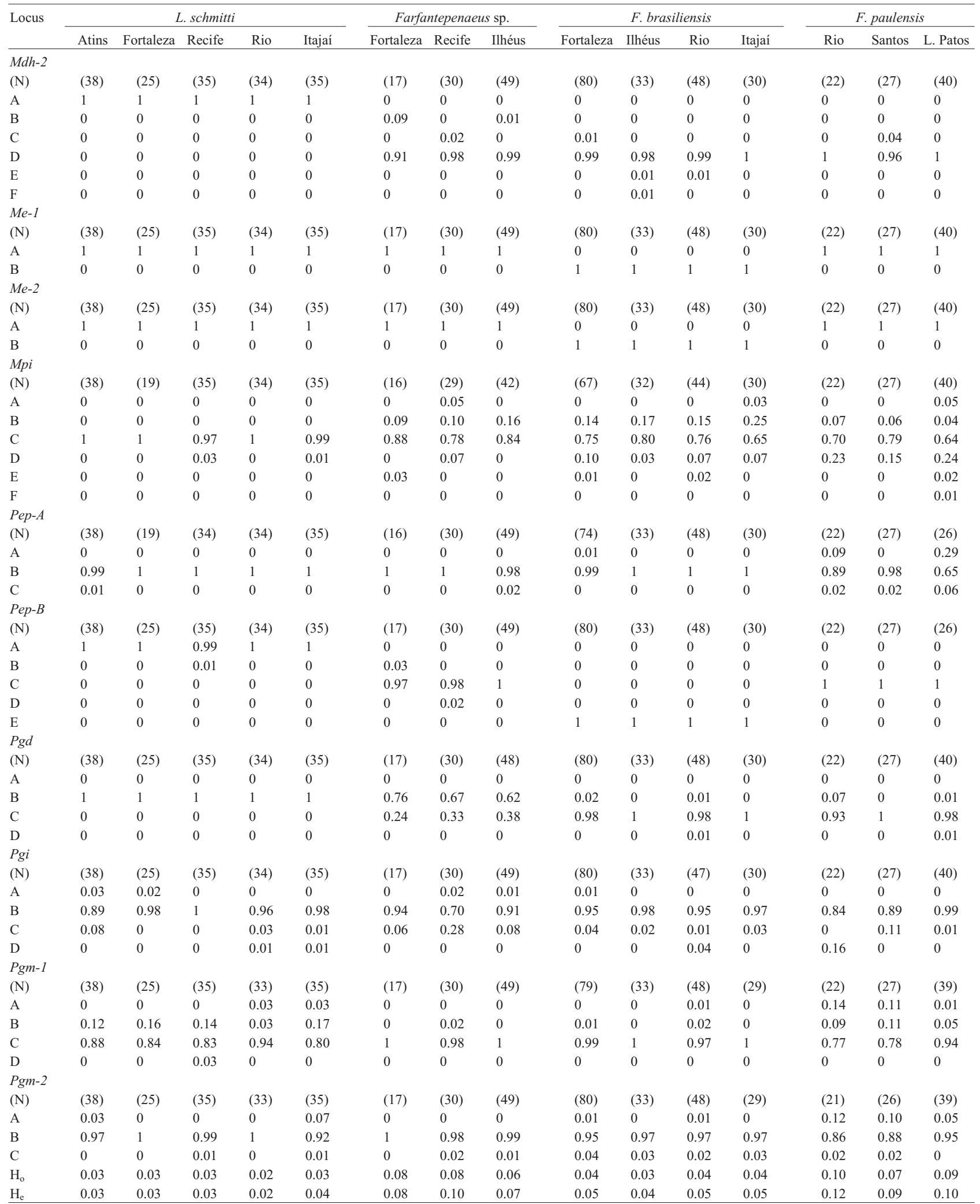

population mixing or a number of actual or artifactual factors (Zouros and Foltz, 1984).
In the same way as observed here, levels of worldwide genetic population structure vary widely between dif- 
ferent species of shrimp, so that populations separated by thousands of kilometres can be genetically more similar than others over very short distances (Benzie, 2000). Some authors have suggested that differences between species in levels of genetic variation and genotype distribution might be related to life history types (Mulley and Latter, 1981; De La Rosa-Velez et al., 2000). Recently, a major survey of published data indicates that historical events, over large biogeographic scales, may explain the patterns observed better than present day dispersal (Benzie, 2000).

The genetic structure observed in wild populations of F. notialis (Espinosa et al., 1996; García-Machado et al., 2001), F . californiensis and of L. stylirostris (De La RosaVelez et al., 2000) as well as those described here for the Brazilian populations of $F$. paulensis and Farfantepenaeus sp., does not seem to reflect large biogeographical events but, rather, patterns of present day dispersal. In Cuba, for example, the genetic differences detected between populations of $F$. notialis collected in the Batabanó and the Ana María Gulfs, which are less than $15 \mathrm{~km}$ apart, could be due to localized recruitment or to temporal variation in allele frequencies (García-Machado et al., 2001). These factors could be directly or indirectly related to the presence of the Calzones Gulf (the deepest in Cuba), which might prevent the movement of larvae and adults.

Further evidence that the patterns of differentiation observed are more likely to reflect present day dispersal, rather than biogeographical patterns in the Brazilian shrimp populations, is that in spite of their different levels of population structuring, the species studied here have quite similar distribution ranges. The two species that did not present any significant population differentiation $F$. brasiliensis and L. schmitti occur from the South of Brazil to the Caribbean, and have wide overlapping zones with the distributions of $F$. paulensis, in the South of Brazil, and of Farfantepenaeus sp. in Southeast and Northeast Brazil. Thus, the incongruence found between their population structure patterns cannot be attributed to common biogeographic boundaries. Moreover, the observed levels of differentiation among populations of $F$. paulensis and of Farfantepenaeus sp. do not seem to indicate a direct correlation with geographic distances (Mantel test, $\mathrm{p}>0.05$ ).

Instead of biogeographic factors, the observed differences in population structure between the four species studied seem to reflect the differences in their biology. Among Brazilian shrimp species, the periods of reproduction, estuary post-larvae penetration and sub-adult emigration vary depending on the species and even among populations of the same species in different geographical regions (reviewed in Gusmão, 2001). Differences in environmental preferences in relation to water temperature, salinity, sediment type and bathymetry are also observed among species (Holthuis, 1980; Paiva, 1997). For example, F. paulensis is found in cold waters where spawning occurs, usually below $50 \mathrm{~m}$ depth, and its migration is more related to depth than to latitude (Zenger and Agnes, 1977). F. brasiliensis and L. schmitti, on the other hand, prefer warmer waters, so that the migration of $F$. brasiliensis is more related to latitude (Zenger and Agnes, 1977).

F. paulensis ranges from Cabo Frio (Rio de Janeiro State - RJ), along the continental shelves of Brazil and Uruguay, to northeast Argentina (Pérez Farfante, 1969; Holthuis, 1980). The main $F$. paulensis offshore fishing area is located between Santos (São Paulo State - SP) and Torres (Rio Grande do Sul State - RS) (Iwai, 1973), but there are two major adult congregation zones: one off Santa Catarina State (SC), and the second between Santos and São Sebastião Island (littoral North of SP; Figure 1) (Zenger and Agnes, 1977; Melquíades, 1997). Important juvenile shrimp populations can be found in the estuaries of Rio Grande do Sul, but no adult breeding grounds are found in the offshore waters of Rio Grande do Sul or Uruguay (Iwai, 1973; Zenger and Agnes, 1977). Data on coastal currents, wind direction and velocity between Florianópolis (SC) and Laguna de Castillo (Uruguay) indicate that the post larvae that populate nursery areas of Lagoa dos Patos and Uruguay may originate in the breeding grounds off Santa Catarina State (D'Incao, 1991). This hypothesis obtained further support from an allozyme study that indicated a high level of genetic homogeneity between populations from both areas (Delevedove, 1996).

The present study shows that the populations of $F$. paulensis from Rio de Janeiro and Santos (Southeast of Brazil) are significantly different from that from Lagoa dos Patos (South). Thus, it is possible that the structuring pattern observed for $F$. paulensis reflects the presence of two breeding populations (stocks) concentrated in different geographic areas along the species range. The Southeastern stock comprises the shrimps living in the Santos/ Rio de Janeiro area, and the Southern stock the shrimps from Santa Catarina/Lagoa dos Patos, and perhaps Uruguay.

Unfortunately, there is little information about the biology of Farfantepenaeus sp. species, which makes discussing the possible causes of the observed population heterogeneity difficult. In addition, the available information to date is based on the overlap of data about the cryptic species F. subtilis and Farfantepenaeus sp. (Gusmão et al., 2000). Nevertheless, despite the factors responsible for the observed structuring patterns, the fact that genetically distinct populations exist in Farfantepenaeus sp. and $F$. paulensis is clear, and should be taken into account for future aquaculture programs and fisheries management of both resources.

\section{Acknowledgments}

The authors would like to thank E. Araújo, F. D'Incao, L. Weber, P. Paiva and P. Vianna for help with collecting the samples and G. Solha for technical assis- 
tance. This work was supported by grants from CAPES, CNPq, FAPERJ, FUJB and PADCT (Brazil).

\section{References}

Aubert H and Lightner DV (1999) Identification of genetic populations of the Pacific blue shrimp Penaeus stylirostris of the Gulf of California, Mexico. Mar Biol 137:875-885.

Benzie JAH (2000) Population genetic structure in penaeid prawns. Aquacult Res 31:95-119.

Benzie JAH, Frusher S and Ballment E (1992) Geographical variation in allozyme frequencies of Penaeus monodon (Crustacea: Decapoda) populations in Australia. Aust J Mar Freshwater Res 43:715-725.

Brewer GJ (1970) An Introduction to Isozyme Techniques. Academic Press, New York.

De La Rosa-Velez J, Escobar R, Correa F, Maqueda M and Torre J (2000) Genetic structure of two commercial penaeids (Penaeus californiensis and P. stylirostris) from the Gulf of California, as revealed by allozyme variation. Fish Bull 98:674-683.

Delevedove GCD (1996) Genética populacional do camarão rosa Penaeus paulensis (Decapoda: Penaeidae) na região estuarina da Lagoa dos Patos, Rio Grande do Sul, e no litoral de Santa Catarina. Msc. Thesis, Oceanography Department, FURG, Rio Grande.

D’Incao F (1991) Pesca e biologia de Penaeus paulensis na Lagoa dos Patos, RS. Atlântica 13:159-169.

Espinosa G, Diaz FR, Paez CJ, Prats HRM and Labacena ME (1996) Biochemical-genetics analysis of the population of Penaeus notialis from La Ensenada de la Broa, Cuba. Rev Invest Mar 17:37-43.

Espinosa G, Zuñiga UB, Pichs YB, Ramos JR, Fernández RD, Ricardo JA and Dios R (2002) Variación genética y morfológica en poblaciones naturales y cautivas del camarón blanco Litopenaeus schmitti en Cuba. CIVA 2002 (http://www. civa2002.org), pp 778-784.

García-Machado E, Robainas A, Espinosa G, Oliva M, Páez J, Verdecia N and Monnerot M (2001) Allozyme and mitochondrial DNA variation in Cuban populations of the shrimp Farfantepenaeus notialis (Crustacea: Decapoda). Mar Biol 138:701-707.

Gusmão J (2001) Sistemática molecular e genética populacional de espécies brasileiras de camarão (Penaeus: Decapoda: Penaeidae). PhD Thesis, Universidade do Brasil, Rio de Janeiro.

Gusmão J, Lazoski C and Solé-Cava AM (2000) A new species of Penaeus (Crustacea: Penaeidae) revealed by allozyme and citochrome oxidase I analyses. Mar Biol 137:435-446.

Hare MP, Karl SA and Avise JC (1996) Anonymous nuclear DNA markers in the American oyster and their implications for the heterozygote deficiency phenomenon in marine bivalves. Mol Biol Evol 13:334-345.

Holthuis LB (1980) Shrimps and prawns of the world. An annotated catalogue of species of interest to fisheries. FAO species catalogue. FAO Fish Synop, Roma 125:1-271.

Iwai M (1973) Pesquisa e estudo biológico dos camarões de valor comercial. Publ esp Inst Oceanogr, 3:501-534.

Lessios HA (1992) Testing electrophoretic data for agreement with Hardy-Weinberg expectations. Mar Biol 112:517-523.
Maggioni R, Rogers AD, Maclean N and D'Incao F (2001) Molecular phylogeny of western Atlantic Farfantepenaeus and Litopenaeus shrimp based on mitochondrial 16S partial sequences. Mol Phylogenet Evol 18:66-73.

Manchenko GP (1994) Handbook of Detection of Enzymes on Electrophoretic Gels. CRC Press Inc., Michigan.

Mattoccia M, La Rosa G, De Matthaeis E, Cobolli Sbordoni M and Sbordoni V (1987) Patterns of genetic variation and differentiation in Mediterranean populations of Penaeus kerathurus (Crustacea: Decapoda). In: Tiews K (ed) Selection, Hybridisation and Genetic Engineering in Aquaculture. ICES, Copenhagen, pp 131-142.

Paiva MP (1997) Recursos Pesqueiros Estuarinos e Marinhos do Brasil. UFC, UFC Edições, 286 pp.

Mulley JC and Latter BDH (1981) Geographic differentiation of Eastern Australian penaeid prawn populations. Aust J Mar Freshwater Res 32:889-895.

Murphy RW, Sites JW, Buth DG and Haufler CH (1990) Proteins I. Isozyme electrophoresis. In: Hillis DM and Moritz C (eds) Molecular Systematics. Sinauer Associates, Massachusetts, pp 45-126.

Neigel JE (2002) Is $\mathrm{F}_{\mathrm{ST}}$ obsolete? Conserv Genet 3:167-173.

Neto JD (1991) Pesca de camarões na costa norte do Brasil. Atlântica 13:21-28.

Neto JD and Dornelles LDC (1996) Diagnóstico da Pesca Marítima do Brasil. Coleção Meio Ambiente (Série Estudos Pesca 20) IBAMA, Brasília, 165 pp.

Pérez Farfante I (1969) Western Atlantic shrimps of the genus Penaeus. Fish Bull 67:461-591.

Pérez Farfante I and Kensley B (1997) Penaeoid and sergestoid shrimps and prawns of the world. Keys and diagnoses for the families and genera. Mem Mus Nat Hist Natur 175:1-79.

Ramos-Paredes J and Grijalva-Chon JM (2003) Allozyme genetic analysis in hatchery strains and wild blue shrimp, Penaeus (Litopenaeus) stylirostris (Stimpson), from the Gulf of California. Aquaculture Res 34:221-234.

Shaw CR and Prasad R (1970) Starch gel electrophoresis of enzymes - A compilation of recipes. Biochem Gen 4:297-320.

Sokal RR and Rohlf FJ (1995) Biometry: The Principles and Practice of Statistics in Biological Research. W.H. Freeman and Co., San Francisco, 850 pp.

Solé-Cava AM and Thorpe JP (1989) Biochemical correlates of genetic variation in marine lower invertebrates. Biochem. Gen 27:303-312.

Sunden SLF and Davis SK (1991) Evaluation of genetic variation in a domestic population of Penaeus vannamei (Boone): A comparison with three natural populations. Aquaculture 97:131-142.

Swofford DL and Selander RB (1981) BIOSYS-1, a FORTRAN programme for the comprehensive analysis of electrophoretic data in population genetics and systematics. J Hered 72:281-283.

Valentini H, D'Incao F, Rodrigues LF, Neto JER and Rahn E (1991) Análise da pesca do camarão-rosa (Penaeus brasiliensis e Penaeus paulensis) nas regiões sudeste e sul do Brasil. Atlântica 13:143-157.

Waples RS (1987) A multispecies approach to the analysis of gene flow in marine shore fishes. Evolution 41:385-400.

Ward RD and Beardmore JA (1977) Protein variation in the plaice (Pleuronectes platessa). Gen Res 30:45-62. 
Whitlock MC and McCauley DE (1999) Indirect measures of gene flow and migration: $\mathrm{F}_{\mathrm{ST}}$ is different from $1 /(4 \mathrm{Nm}+1)$. Heredity 82:117-125.

Wright S (1978) Evolution and the Genetics of Populations. The University of Chicago Press, London. 580 pp.

Zenger Jr HH and Agnes JL (1977) Distribuição do camarão-rosa (Penaeus brasiliensis e Penaeus paulensis) ao longo da costa sudeste e sul do Brasil. Ser Doc Tec (SUDEPE-PDP) 21:1-105.

Zouros E and Foltz DW (1984) Possible explanations of heterozygote deficiency in bivalve molluscs. Malacologia 25:583-591.

Associate Editor: João S. Morgante 